\title{
THE HOSPITAL WORKSHOP.
}

\section{IX.-OUT-PATIENTS AT ST. BARTHOLOMEW'S.}

(BY OUR SPECIAL COMMISSIONER.)

So far as out-patients are concerned, St. Bartholomew's is the most frequented hospital in town, a fact abundantly proved by the following figures taken for the year 1887 . Out.patients :

$\begin{array}{lrrr}\text { St. Bartholomew's. } & 150,828 \text { (including casualties). } \\ \text { London .............. } & 95,760 & \text { ", } & , \\ \text { St. Thomas's ….. } & 87,601 & , & , \\ \text { University College. } & 44,382 & \text { ", } & \text { ", } \\ \text { Guy's .................. } & \mathbf{3 7 , 8 6 5} & \text { ", }\end{array}$

It is seldom easy to make out exactly the reasons that guide and govern the populace. Here, however, their liking seems to be due to a number of different causes working together. 1. Patients receive attention quickly and at convenient hours. They come at nine o'clock in the morning, and are seen by members of the assistant staff. Slight cases have immediate treatment, while the more serious are directed to come again at 12.30 p.m. 2. Central position of the hospital, with no other great institution of the kind in the near neighbourhood. 3. Popularity of staff. 4. Rapidity of dispensing. 5. Freedom of admission. 6. The oldestablished reputation of the charity, which was founded in 1122. Sir James Paget lately pointed out that the first King Henry granted their original charter, and that the present one was given by the last King Henry.

An attempt is made to prevent abuse of the out-patient department by well-to-do people. In a letter which recently appeared in the British Medical Journal, Dr. Rentoul writes: "The St. Bartholomew's Hospital System.-Here, also, is an enquiry officer, who is paid $£ 156$ yearly. The secretary says he 'draws the patients' attention to the fact that the hospital is a charitable institution, designed for the relief only of the necessitous poor.' In 1882, the year previous to the appointment of an inspector, the number of casualty and out-patients Was 170,030, while last year the total number was 144,681 ; a falling off of 25,349. Compare this plan with the very doubtful one pursued at Guy's Hospital, where they charge the sick poor threepence for advice and medicine. Who introduced this iniquitous system of a medical charity actually selling its charity?"

At 12.30 p.m. your commissioner, under the guidance of a student, went to the waiting-room for the surgical cases "sent in from the nine o'clock inspection. In this place the "dressers" take careful notes of patients before passing them in for consultation. On entering, Mr. Butlin, the surgeon for the day, had before him a man with a swollen anklejoint. The students were being questioned, one at a time, as to history, treatment, and symptoms, a reason being called " for every answer given. In this way, which is called "quizzing" by the Americans, the utmost is made of material from an educational point of view.

Crossing over to the medical branch, we enter a light and well-ventilated room where patients are seated waiting their turn for advice. At the particular moment of our arrival a to her faced girl with a smart bonnet is showing her tongue to her next-door neighbour. Without any great effort of what then it may be guessed that she is suffering from what the doctors call "anæmia," or poverty of blood, and the she is taking iron, a remedy which is apt to blacken of tongue. Let us look at her card. She is nineteen years cof age, a tailoress from Ludgate-hill. When admitted she in joints of pains all over the body -in chest, in heart, and in joints. Breath short; easily fatigued; has been in this junctiva for two years. The mucous membrane of conbloodless (i.e., inside of eyelid), and also of lips, is pale and Heart Feet and legs sometimes swell in the morning. anæmia" pretty sound. The disease is entered as "morbid anæmia," and the medicine is citrate of iron and ammonia, a mild, blood-forming tonic. Under a course of prolonged treatment no doubt the girl's health will be very much improved ; but good food and fresh air are almost as important as physic in these cases. "Anæmia" is a common disorder amongst those who have to spend their days in crowded workshops, and whose meagre earnings are often swallowed up by the demands of home. As a result, underfeeding is added to the burden of overwork and unhealthy surroundings, and the hospitals are crowded by these pale victims of a cruel industrial warfare.

In the consulting-room several persons are under examination. One is a dock-labourer from Poplar. He is fiftynine years of age, and is sitting with hand pressed across the pit of his stomach. There is a somewhat anxious expression upon his weather-beaten face. Of late he has been losing flesh rapidly, and complains that he can no longer swallow solid food. There has been no pain, neither has he spat blood at any time, although he now brings up a quantity of watery fluid. The chest is barrel-shaped, owing to enlargement of the lungs from distension of the air-cells. Dr. Habershon's notes describe the patient as " a tall, spare man, with well-marked emphysema" (the state of lung mentioned above). Unhappily, there can be no doubt this case is one of malignant-that is to say, cancerous-disease of the stomach, which will run a rapid course, and against which treatment will be of little avail.

The arrangements for dispensing, an important part of the out-patient department, seem to be especially good. Most of the preparations are made in the compounding-room, excepting a few, such as the alkaloids and green extracts, which are bought along with the chemicals. By this means purity is ensured, as well as a great saving effected to the funds of the hospital. Without attempting anything like an elaborate description, some few points of interest may be noted for the behoof of readers. Near the entrance, worked round and round at high speed by steam power, are two millstones for grinding various crude drugs, such as rhubarb, senna, jalap, and bark, into powders. Hard by is a sifting-machine, which consists of a sieve fixed in a barrel, the whole being thoroughly shaken up by means of a simple yet ingenious eccentric motion. Other advanced appliances of the modern chemical laboratory are to be seen on every side. Here, for instance, enclosed in steamjacket pans, are two basins for making the acid preparations. They are of platinum, the only metal capable of resisting the action of acids for any length of time; and must be very costly, not less than a couple of hundred pounds apiece at a rough guess. Their small size contrasts sharply with the huge mortar standing close by, and which looks as if it had strayed from the kitchen of some pantomime giant. His club might well be the pestle, a beam some three feet long, and worked in eccentric movement at the rate of 36 revolutions a minute. Nor is the provision of drugs on a less gargantuan scale. Sacks of Tinivelly senna, of gentian and of cinchona bark lie heaped on one side; here is a bin, high as a man's chest, filled with crushed poppy capsules. The latter are used chiefly for preparing syrup of poppies, that famous old remedy for cough mixtures. The dispenser tells us this bin is emptied eight times in the six months. The next compartment, of equal size, is for linseed meal, of which half a ton is consumed every two or three weeks, less being ordered in summer than in winter. Other crude drugs are stored up in various bins and crates; treacle is kept in large quantity for grinding up with powders into pill-mass. Down the room is ranged a row of twelve gallon jars, reminding one irresistibly of Ali Baba twelve gallon jars, remerty thieves. Over yonder are two big tanks-one of which holds olive and the other cod-liver oil. This line of casks contains the commoner medicines of the hospital 
pharmacopœia, made up ready for dispensing. Each of them, when filled, will last from one to three days. But not less than eighteen gallons daily are wanted of a quassia and iron mixture, and a similar quantity of a saline draught, known as " house mixture." Water is proverbially the right hand of the dis penser, and the wholesale production of physic that goes on here requires an apparatus capable of distilling some seventy gallons in a day.

On one side of the spirit-room are four pipes of wine, three of port, and the other of sherry. Opposite stand a row of tanks, one for whisky, another of a hundred galllon capacity for brandy, and a third twice that size for proof alcohol.

A few facts and figures of this kind will bring home to the reader an idea of the vastness of a charity which dis. penses medicines in such titanic fashion. Dispensing is a very important part of the hospital machinery, and on its accuracy and the purity of its drugs must in a large measure depend the success of medical treatment. It is a department requiring no less energy in administration than constancy of supervision to ensure proper working From what we have personally seen, St. Bartholomew's wil bear favourable comparison in these respects with any of the great medical charities.

\section{ÁMUSEMENTS AND RELAXATION.}

\section{Second Quarterly Word Competition Commenced July 6th, ends September 28th.}

Three Prizes of $15 \mathrm{~s} ., 10 \mathrm{~s} ., 5 \mathrm{~s}$, , will be given for the largest number of words derived from the words set for dissection.

Proper names, abbreviations, foreign words, words of less than fou letters, and repetitions are barred; plurals, and past and present par ticiples of verbs, are allowed. Nuttall's Standard dictionary only to be sed.

N.B.-Word dissections must be sent in WEEKLY, arranged alpha betically, with correct total affixed.

The word for dissection for this, the Tenth week of the quarter, being "B A R M O U T H."

\section{Results of Eighth week.}

\begin{tabular}{|c|c|c|c|c|c|}
\hline ames. & 28 & Totals. & Names. $A u_{g}$ & $29 \mathrm{t}$ & To \\
\hline urse Duty & 21 & .. 481 & Leirion..$\ldots \ldots$. & & 195 \\
\hline N'importe Qui .. & 19 & .. 440 & Matron ... & - & 174 \\
\hline Jumps........... & - & 30 & F. C. J. & . & 305 \\
\hline Tinie .... & - & 186 & Percy Verance... & - & 18 \\
\hline Patience... & 21 & 487 & Gleniffer....... & & 175 \\
\hline Amicus ... & - & 430 & Gypsye ... & 21 & 422 \\
\hline Broxbourne .... & - & 398 & Ladyr .. & & 127 \\
\hline Speedwell. & 20 & 439 & A. B. & 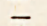 & 170 \\
\hline Sister & 19 & 463 & Essie & 19 & 380 \\
\hline Lightowlers .... & 21 & 356 & W. G. R.. & 19 & 375 \\
\hline Lauriston ....... & 21 & 345 & Cowboy Bill & - & 179 \\
\hline Rattler & - & 28 & M. L. A. ... & & 117 \\
\hline Paignton . & - & 334 & Little Tuppy..... & - & 110 \\
\hline Fassifern. & - & 141 & Embryo .... & & 56 \\
\hline W. R. E.... & 20 & 468 & K. Jarman. & & 43 \\
\hline Esperance.. & 20 & 480 & Reveal.. & 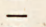 & 196 \\
\hline M. W. ... & 20 & 485 & Jenny Wren & 19 & 372 \\
\hline Isabel ...... & 21 & 454 & Condorcet & 20 & 406 \\
\hline Buxton & - & 167 & Electrician.. & 20 & 245 \\
\hline Nux Vom & - & 263 & Pearl & & 132 \\
\hline Qu'appelle....... & 20 & 419 & R. W. .. & - & 43 \\
\hline Spes......... & - & 24 & Nurse Amie & - & $\begin{array}{l}80 \\
89\end{array}$ \\
\hline Secnarf & - & 229 & Sunshine......... & 19 & .. 162 \\
\hline Rover ..... & 20 & 226 & Juvenis & & 23 \\
\hline
\end{tabular}

N.B.-All letters referring to this page which do not arrive at 139 and 140. Salisbury-court, London, E.C., by the first post on Thursdays, and 140, Salisbury-court, Lot addressed PRIZE EDITOR, will in future be disqualified and disregarded

Competitors can enter for all quarterly competitions, but no competitor may take more than two quarterly prizes during the year.

\section{Conditions.} I. Every paper sent in must be clearly written, and one side only must
be used. All competitors must mark at the head of their papers the Demper of their competition.

II. Each paper must be signed by the author with his or her real name and address. A nom de plume may be added if the writer does not desire to be referred to by us by his real name. In the case of all prize-winners, to be referred to by us by his real name. In the case of III. All communtcations relating to prize competitions should be ad. dressed to "The Prize Editor, THE HOSPITAL, 139 and 140, Salisbury court, London, E.C." Competitors are requested not to include in letters, etc., to the Prize iditor communi

IV. The Prize Editor of THE HOSPITAL is the sole judge of the com petitions, and his decision is in all cases final and without appeal.

V. The Prize Editor reserves the right to publish any paper sent in whether it receives a prize or not. He does not hold himself responsible
for any MSS. sent, nor can he undertake to return rejected competitions.

\section{SCRAPS AND GLEANINGS.}

THERE are 300 cases of fever in Cairo Hospital.

THE death is announced of Dr. W. C. S. Miller, of Edinburgh.

SIR ANDREW CLARK has gone to Bewdley for a couple of months.

THE late medical staff of Belfast Royal Hospital have been re-elected.

CLACTON-ON-SEA collected $£ 50$ on Hospital Saturday. Bravo, Clacton!

DR. CORFIELD reports a further spread of enteric fever at the West End.

THE body of the late Colonel Tomline was cremated at Woking last week.

CHELMSFORD is waking up; it actually proposes to start a Hospital Saturday.

DR. OLIVER WENDELL HOLMES celebrated his 80th birthday at Boston last week.

THE Bill for the establishment of a Dublin Hospital Board has been withdrawn.

DR. SOPHIA UNGER has been appointed the first lady sanitary inspector in New York.

THE ambulance station at Homerton Fever Hospital has been destroyed by fire.

THE Ven. Archdeacon Lawrance preached the sermon at St. Albans on Hospital Sunday.

THERE is a fever epidemic in Constantinople owing to the extreme heat of the weather.

DR. TUNSTALL has been appointed assistant medical officer to Birmingham Workhouse.

MRS. T. MEADOWs has furnished one of the wards of the new Eye Infirmary at Hereford.

THE Thakore of Bhownagur has given Rs.200,000 towards the Bombay Hospital for training nurses.

THF insanitary condition of Alexandria was denounced at the late congress as a danger to all Europe.

DR. MORRICE has been appointed resident medical officer of the Homerton Asylums' Board Hospital.

THE Working Men's Committee of Hull Hospital issue a special appeal for funds to free their institution from debt.

DR. BARSHAM has resigned his connection with Luton Cottage Hospital, and Dr. Clarke has been elected in his stead.

Mr. Charles Brown, house surgeon at St. Thomas's, died last week of diphtheria contracted in the course of his duties.

THF first International Congress of Physiologists will be opened at Basle o. September 10th, and will sit for three days.

DR. FRED. H. HEATH has resigned his connection with Manchester Royal Infirmary, which has existed for over 30 years.

Two cases of cholera are reported to həve occurred in Hungary, near the Austrian frontier. One of them has ended fatally.

A LADY named Sampson committed suicide last week by thrusting the handle of a mirror down her throat and causing suffocation.

HULL and Seulcoates Dispensary Committee have passed a motio expressing their deep regret at the de ath of Alderman Willows, J.P.

THE Central London Poor Law Guardians have decided to erect a tempral to hospital to 400 ophthalmic HOSPITAL SUNDAY at Eastbourne resulted in a collection of $£ 425$. Not very grand, considering the number of visitors to that town just

DURING 1888 the Warwick Cottage Hospital has received 38 in-patients, and the dispensary attached to it has treated 6,800 out-patients, an made up 20,000 prescriptions.

KING'S COLLEGE HOSPITAL nurses scarlet fever, measles, etc., and is the only general hospital which takes infectious cases. All the fevers are nursed in the same ward.

THERE is news from Montrond, in France, of a plague of butterflies. This week the inhabitants have had to keep their windows and doors shut against an influx of the insects.

THE Twickenham friendly and other societies' hospital demonstrations, in aid of St. John's Hospital, Twickenham, and Richmond Hospital, wi be held on Saturday, September 7

A MARRIAGE will shortly take place between Deputy Surgeon-General George Alder Watson, Bengal Army (retired), and Beatrice, daugh

THE Dowager-Empress Augusta visited the Augusta Hospital on the 17th ult., stayed a short time in the Royal Palace Unter den Linden, gave several audiences, and returned to Schloss Babelsberg the same day.

BARON VICTOR PEREIRA, a wealthy Austrian nobleman a descendant of the celebrated Vienna banker, and a member of the yper Austrian Vienna lunatic asylum.

THE Canadian Government has requested a member of its veterinary staff, Dr. Johnson, who happens to be in Paris, to make some enquiries into the discoreries of M. Pasteur, in connection with innoculation as preventative of anthrax and pleuro-pneumonia.

AT Homerton, on August 29th, Dr. G. C. Miller, the chairman of the Hackney Board of Guardians, laid the foundation-stone of a new block of buildings to be erected at a cost of $£ 20,000$ for the purpose of giving increased workhouse accommodation to Hackney.

DROITwICH is well filled with visitors, many of whom are taking the DRoITwICH is well fare at brine baths for which this health resort is famous. Staying theck, pir Henry Edwards, Major-General Montrol

A RoMan CATHOLIC priest of Chasetown has accused Mr. Gettings, the medical officer of Lichfield Union, of permitting his unqualified assistant to attend patients, and of signing unsatisfactory certificates of death. Mr. Gettings says the charges arise from personal malice and are founded. 